\title{
発達性読み書き障害児群における語流暢性課題成績
}

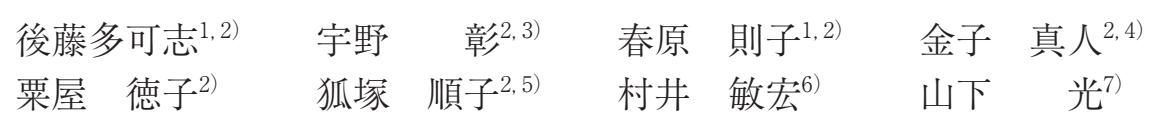

要 約：先行研究では, 発達性読み書き障害児/者の語音想起力を語流暢性課題にて検討し た報告が散見されるが，現在も一定の見解にはいたっていない，本研究では，日本語話者で言 語発達障害のない発達性読み書き障害典型群と特異的言語障害の併存が認められる発達性読み 書き障害群に対して語流暢性課題を実施し, 発達性読み書き障害児の語音想起力について検討 した．対象児は小学校 $1 ， 3 ， 5$ 年生の発達性読み書き障害児 63 名（典型例 50 名, 特異的言語 障害併存例 13 名）と通常学級在籍児 151 名である。語頭音を「あ」と「か」に指定した語流 暢性課題を実施した。通常学級在籍児群と比較して全学年で語頭音指定語流暢性課題の成績が 低かったのは, 発達性読み書き障害/特異的言語障害併存群のみであった。語流暢性課題の成 績には音声言語の発達が関与しており, 言語発達障害のない典型的な発達性読み書き障害児は, 語流暢性課題では問題を示さないと考えられた。

索引用語：発達性読み書き障害, 特異的言語障害, 語流暢性課題, 語音想起障害

\section{Word Fluency Abilities in Japanese Children with Developmental Dyslexia}

\begin{abstract}
Takashi Goto ${ }^{1.2)}$, Akira Uno ${ }^{2.3)}$, Noriko Haruhara ${ }^{1,2)}$, Masato Kaneko ${ }^{2,4)}$, Noriko Awaya ${ }^{2)}$, Junko Kozuka ${ }^{2,5)}$, Toshihiro Murai ${ }^{6}$ and Hikari Yamashita ${ }^{7)}$
\end{abstract}

\begin{abstract}
We analyzed the word sound finding abilities of Japanese children with developmental dyslexia, with and without developmental language disorder, using word fluency tasks. We evaluated the number of correct words in alliteration fluency tasks with
\end{abstract}

目白大学保健医療学部 ${ }^{11}$ ：テ339-8501 埼玉県さいたま市岩槻区浮谷 320

NPO 法人 LD ・ Dyslexia センター2)：７272-0033 千葉県市川市市川南 3-1-1-315

筑波大学人間系 ${ }^{3)}:$ ₹ 305-8572 茨城県つくば市天王台 1-1-1

国士舘大学文学部 ${ }^{4)}$ : $7154-8515$ 東京都世田谷区世田谷 4-28-1

武蔵野大学人間科学部 ${ }^{5)}$ : $=202-8585$ 東京都西東京市新町 1-1-20

平群町立平群小学校 ${ }^{6)}$ : $=636-0932$ 奈良県生駒郡平群町吉新 2-2-13

愛媛大学教育学部 ${ }^{7)}$ ：干790-8577 愛媛県松山市文京町 3 番

${ }^{1)}$ Faculty of Health Sciences, Mejiro University: 320, Ukiya, Iwatsuki-ku, Saitama-shi, Saitama 339-8501, Japan

${ }^{2}$ LD/Dyslexia Centre: 3-1-1-315, Ichikawa-minami, Ichikawa, Chiba 272-0033, Japan

${ }^{3}$ Faculty of Human Sciences, University of Tsukuba: 1-1-1, Tennoudai, Tsukuba, Ibaraki 305-8572, Japan

${ }^{4)}$ Faculty of Letters, Kokushikan University: 4-28-1, Setagaya, Setagaya-ku, Tokyo 154-8515, Japan

${ }^{5}$ Faculty of Human Sciences, Musashino University: 1-1-20, Shinmachi, Nishitokyo, Tokyo 202-8585, Japan

${ }^{6}$ Heguri Elementary School: 2-2-13, Yoshishin, Heguricho, Ikomagun, Nara 636-0932, Japan

${ }^{7}$ Faculty of Education, Ehime University: 3 Bunkyo-cho, Matsuyama, Ehime 790-8577, Japan

2015 年 4 月 24 日受稿 2015 年 11 月 25 日受理 
the given sounds /a/ and $/ \mathrm{ka} /$ of 151 children in regular classes and 63 children with developmental dyslexia (13 with and 50 without specific language impairment) who were in the first, third and fifth grades of elementary school. Only the children with developmental dyslexia and specific language impairment had lower scores in the alliteration fluency tasks than the children in regular classes, for all grades. These results suggest that scores in word fluency tasks connect with spoken language development and do not decrease in Japanese children with developmental dyslexia without developmental language disorder.

Key words: developmental dyslexia, specific language impairment, word fluency task, word sound finding difficulty

\section{はじめに}

発達性読み書き障害（developmental dyslexia）の 背景となる認知障害仮説の 1 つに語音想起障害説があ $る^{1)}$ ，発達性読み書き障害児/者は，音韻障害の背景 となる音韻表象の活性化の問題があると考えられてい るためである21.

先行研究では, 発達性読み書き障害児/者の語音想 起力を語流暢性課題（word fluency task）にて検討 した報告が散見される ${ }^{2-7)}$ 。語流暢性課題は，一定の 制限時間内に口頭表出される単語項目数を指標とし た，長期記憶に基づく語彙検索課題である ${ }^{8}$. 語流暢 性課題は, 意味カテゴリー指定（動物，果物および野 菜等) 課題と, 語頭音指定 ( $\mathrm{F} / \mathrm{A} / \mathrm{S}$, あ/か/儿等) 課 題に大別されるが ${ }^{8)}$, 語流暢性課題の構成概念妥当性 を検討した結果，語頭音指定課題が読み書きの因子に 寄与していたという報告があり ${ }^{9)}$ ，発達性読み書き障 害児/者を対象とした研究においては語頭音指定の語 流暢性課題が用いられることが多い.

しかし, 語頭音指定の語流暢性課題を用いて発達性 読み書き障害児/者の語音想起力を検討した研究では, 典型発達児と比較して得点低下を認めたとする報 告 ${ }^{2-6)}$ と認めなかったとする報告 ${ }^{7)}$ があり，現在も一 定の見解にいたっていない。また，語流暢性課題は語 彙力との関連が示唆されていることから ${ }^{10)}$, 対象を言 語発達障害のない発達性読み書き障害典型例と, 言語 発達障害の併存を認める発達性読久書き障害児すなわ ち特異的言語障害 (specific language impairment; SLI）併存例に分けて検討する必要があると考えられ るが, 先行研究では十分な統制が行われていない.

そこで本研究では, 日本語話者で言語発達障害のな い発達性読久書き障害児群と, 特異的言語障害の併存 が認められる発達性読み書き障害児群に語頭音指定の 語流暢性課題を実施し, 発達性読み書き障害児の語音 想起力について検討することを目的とする.

\section{方法}

\section{1. 対象 (表 1,2)}

1 ）通常学級在籍児

通常学級在籍児 (children in regular classes; 以下 $\mathrm{RC})$ は，大阪府と奈良県の公立小学校に在籍する 1 年生, 3 年生㧍よび 5 年生の計 151 名である ${ }^{11)}$ 。なお, 医療機関にて発達障害の診断を受けている児童は対象 から除外されている.

2 ) 発達性読み書き障害児（典型例，特異的言語障 害併存例)

発達性読み書き障害児は, LD (learning disabilities）览/者へのサポート専門機関に来所した小学 1 年生, 3 年生㧍よび 5 年生の児童 63 名で, 典型例 (developmental dyslexia；以下 DD) 50 名, 特異的言 語障害併存例 (developmental dyslexia \& specific language impairment；以下 DD+SLI）13名である. DD 群は，下記(1)(2)(3)のすべての条件を満たす児童と した。すなわち，(1) WISC-III（Wechsler Intelligence Scale for Children-Third Edition)の言語性 IQ (Verbal Intelligence Quotient; VIQ）\&しくは動作性 IQ (Performance Intelligence Quotient; PIQ)，または WISC-IV (Wechsler Intelligence Scale for ChildrenFourth Edition) の言語理解指数 (Verbal Comprehension Index; VCI) もしくは知覚推理指数 (Percep-

\begin{tabular}{|c|c|c|c|c|c|c|}
\hline \multirow[t]{2}{*}{ 学年 } & \multicolumn{2}{|c|}{$\begin{array}{c}\mathrm{RC} \\
(\mathrm{n}=151)\end{array}$} & \multicolumn{2}{|c|}{$\begin{array}{c}\text { DD } \\
(n=50)\end{array}$} & \multicolumn{2}{|c|}{$\begin{array}{c}\mathrm{DD}+\mathrm{SLI} \\
(\mathrm{n}=13)\end{array}$} \\
\hline & 男児 & 女児 & 男児 & 女児 & 男児 & 女児 \\
\hline 小 1 & 32 & 37 & 3 & 2 & 2 & 1 \\
\hline 小 3 & 23 & 27 & 17 & 5 & 3 & 0 \\
\hline 小 5 & 17 & 15 & 21 & 2 & 6 & 1 \\
\hline
\end{tabular}


表 2 発達性読み書き障害児 $(n=63)$ の認知神経心理学的所見

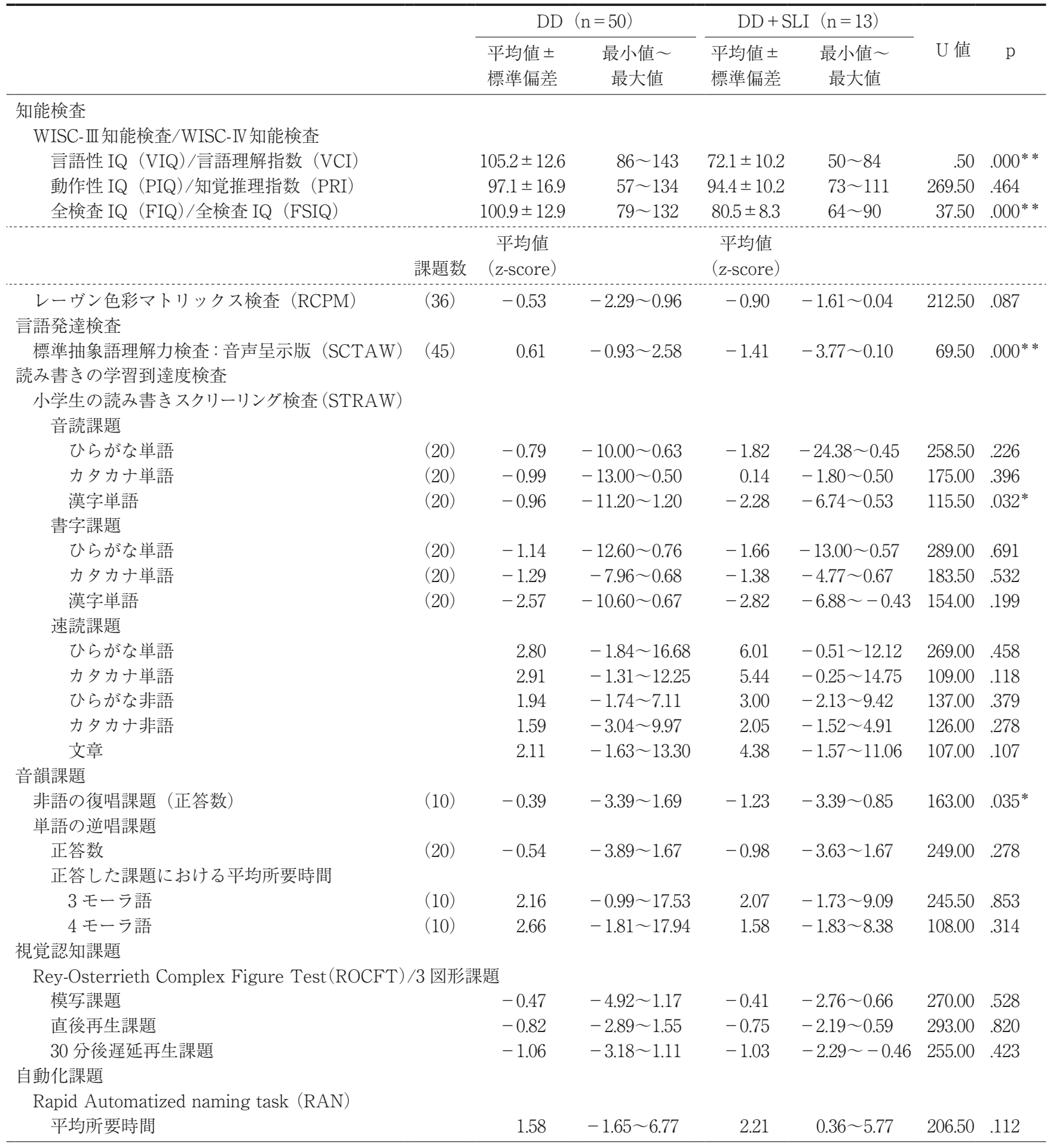

DD：発達性読み書き障害典型例, DD + SLI : 発達性読み書き障害/特異的言語障害併存例

RCPM, SCTAW, STRAW およびROCFTの Z-score は, 宇野ら ${ }^{12,13)}$ が公表した基準值を基に算出した.

速読課題の $z$-score は, 春原ら ${ }^{14)}$ が公表した基準值を基に算出した.

単語の逆唱課題と RANの Z-score は, 篠田ら ${ }^{15)}$ が公表した基準値を基に算出した。

非語の復唱課題の Z-score は，典型発達児 212 名の基準值（未公表）を基に算出した。

3 図形課題の $z$-score は典型発達児 116 名の基準值（未公表）を基に算出した.

レーヴン色彩マトリックス検査（Raven’s Coloured Progressive Matrices; RCPM)

標準抽象語理解力検査 (The Standardized Comprehension Test of Abstract Words; SCTAW)

小学生の読み書きスクリーニング検査 (Screening Test of Reading and Writing for Japanese Primary School Children; STRAW)

統計解析には, Mann-WhitneyのU検定を用いた. * : p <.05, ** : p <.01 
tual Reasoning Index; PRI) で 85 以上を示すか, レー ヴン色彩マトリックス検査 (Raven's Coloured Progressive Matrices; RCPM) に打いて同学年平均 -1 標準偏差以上の得点を示す。 (2)小学生の読み書きスク リーニング検査 ${ }^{12)}$ (Screening Test of Reading and Writing for Japanese Primary School Children; STRAW）のひらがな単語, カタカナ単語および漢字 単語の読み書きの正確性において1 項目でも平均 -1.5 標準偏差值未満の得点を示すか, 速読課題 ${ }^{14)}$ のひら がなとカタカナの単語と非語, 文章課題のうち, 1 項 目でも平均 +1.5 標準偏差值より長い所要時間の延長 を示す. (3)非語復唱課題もしくは単語逆唱課題の正答 数が平均 -1.5 標準偏差值未満の得点を示すか, 単語 逆唱課題で正答までに掛かった時間が平均 +1.5 標準 偏差值より長い延長を示すか, Rapid Automatized naming task (RAN) で平均 +1.5 標準偏差值より長 い所要時間を示すか, 視覚認知課題 ( 1 年生 : 三図形 課題 ${ }^{14}$ ， 3 年生と 5 年生 : Rey の複雑図形課題 (ReyOsterrieth Complex Test; ROCFT) ) の模写課題, 直 後再生課題および 30 分後遅延再生課課題のいずれか で平均 -1.5 標準偏差值未満の得点を示す, である. 一方, DD + SLI 群は, 上述の DD 群の条件を満たし かつ下記の条件を満たす群とした。すなわち, WISC-III VIQ もしくは WISC-IV の VCI か標準抽象 語理解力検查 (The Standardized Comprehension Test of Abstract Words; SCTAW) のいずれか一方, あるいは双方で平均 -1 標準偏差未満の得点を示す, という条件である。

表 2 にD 群と DD + SLI 群の初診時における認知 神経心理学的所見を示した. ウェクスラー式知能検査 (WISC-III, WISC-IV) では, VIQもしくはVCI の平 均が DD 群 105.2/DD + SLI 群 72.1, 全検査 IQ（Full Scale Intelligence Quotient; FIQ もしくは FSIQ) の 平均が DD 群 $100.9 / \mathrm{DD}+\mathrm{SLI}$ 群 80.5 であった. VIQ もしくはVVIと, FIQもしくはFSIQに扔いて2 群 間に $1 \%$ 水準で有意差が認められ，双方とも DD+ SLI 群は DD 群よりも成績が低かった. PIQ もしくは PRI の平均は, 両群とも 90 以上であった.レーヴン 色彩マトリックス検査 (Raven's Coloured Progressive Matrices; RCPM) における平均 $\mathrm{z}$ 得点は, 両群とも-1 以上であった. SCTAW の平均 $\mathrm{z}$ 得点は, DD 群 $0.61 / D D+S L I$ 群 -1.41 で 2 群間に $1 \%$ 水準で 有意差が認められ, DD + SLI 群は DD 群よりも得点 が低かった. STRAW ${ }^{12)}$ の平均 $\mathrm{z}$ 得点は, DD 群はひ らがな, カタカナおよび漢字単語の書字課題, $\mathrm{DD}+$
SLI 群はひらがなと漢字単語の音読課題と, ひらがな, カタカナおよび漢字単語の書字課題でー1未満であっ た. 漢字単語の音読課題は, DD 群 $-0.96 / \mathrm{DD}+\mathrm{SLI}$ 群 -2.28 で 2 群間に $5 \%$ 水準で有意差が認められ, $\mathrm{DD}+\mathrm{SLI}$ 群は DD 群よりも得点が低かった. 速読課 題 ${ }^{14)}$ の平均 $z$ 得点は, 両群ともすべての課題で +1.5 以上であった. 非語復唱課題の正答数における平均 $z$ 得点は, DD 群 - 0.39/DD + SLI 群 - 1.23で 2 群間に $5 \%$ 水準で有意差が認められ, DD+SLI 群は DD 群より も得点が低かった。単語逆唱課題の正答数における平 均 $z$ 得点は, 両群とも -1 以上であった。一方, 単語 逆唱課題で正答までに掛かった時間の平均 $z$ 得点は, 両群とも 3 モーラ語，4 モーラ語双方に扔いて +2 以 上であった。視覚認知課題 (1 年生 : 三図形課題 ${ }^{14)}$, 3 年生と 5 年生 : ROCFT) の平均 $\mathrm{z}$ 得点は, 両群と も模写課題と直後再生課題は-1 以内, 30 分後遅延再 生課題は-1 未満であった. RAN の所要時間は, 両 群とも平均 $+1.5 \mathrm{z}$ 得点以上であった.

\section{2. 手続き}

語頭音指定の語流暢性課題を実施した。手続きは村 井ら ${ }^{11)}$ に従った。すなわち，対象には「あ」から始 まる単語と「か」から始まる単語を口頭で答えてもらっ た. 制限時間は 1 分間とした. 表出された単語のうち, 固有名詞 (人名, 地名) や数詞は除外し, 各課題の単 語想起数を $\mathrm{RC}$ 群, $\mathrm{DD}$ 群および DD + SLI 群の 3 群 で比較した。解析には Kruskal-Wallis 検定を使用した。

\section{結果（図 1)}

全学年において, 語頭音「あ」と「か」の語流暢性 課題における単語想起数に 3 群間で有意差が認められ た（小学 1 年生 :「あ」 $\mathrm{df}=2, \chi^{2}=6.70, \mathrm{p}=.035$,「か」 $\mathrm{df}=2, \quad \chi^{2}=6.08, \mathrm{p}=.048, \quad$ 小学 3 年生 :「あ」 $\mathrm{df}=2$, $\chi^{2}=8.37, \mathrm{p}=.015, \Gamma$ か $」 \mathrm{df}=2, \quad \chi^{2}=8.20, \mathrm{p}=.017$, 小学 5 年生 : 「あ」 $\mathrm{df}=2, \quad \chi^{2}=10.95, \mathrm{p}=.004,\lceil$ か $\left.\mathrm{df}=2, \quad \chi^{2}=12.98, \mathrm{p}=.002\right)$.

多重比較の結果, 小学 1 年生の語頭音「あ」の成績 に执いて, DD 群と DD + SLI 群の間に有意差が認め られた $(\mathrm{p}=.030)$. 語頭音「か」の成績は, $\mathrm{RC}$ 群と $\mathrm{DD}+\mathrm{SLI}$ 群の間で有意差が認められた $(\mathrm{p}=.043)$ ．小 学 3 年生の語頭音「あ」と「か」の成績において, $\mathrm{DD}$ 群と DD + SLI 群の間に有意差（「あ」: $\mathrm{p}=.047$, $\lceil$ か： $\mathrm{p}=.025 ）$ が認められた。学 5 年生に打ける語 頭音「あ」と「か」の成績は, RC 群と DD + SLI 群 の間に有意差（「あ」: $\mathrm{p}=.005$,「か」: $\mathrm{p}=.004)$ が認め られた。 

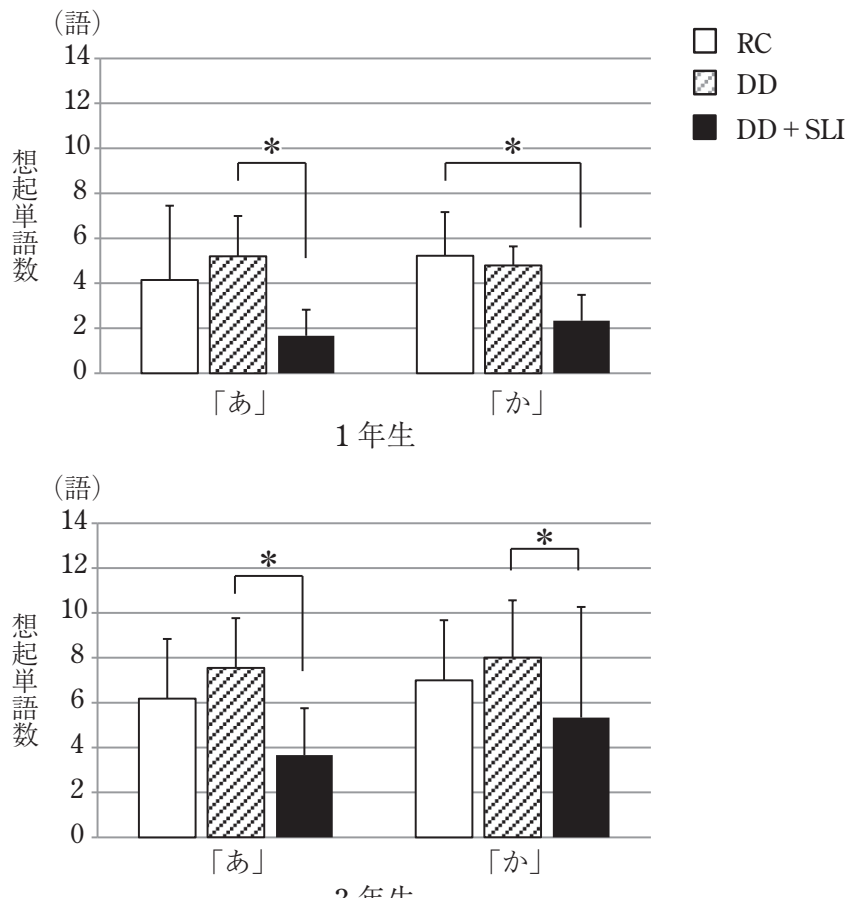

3 年生

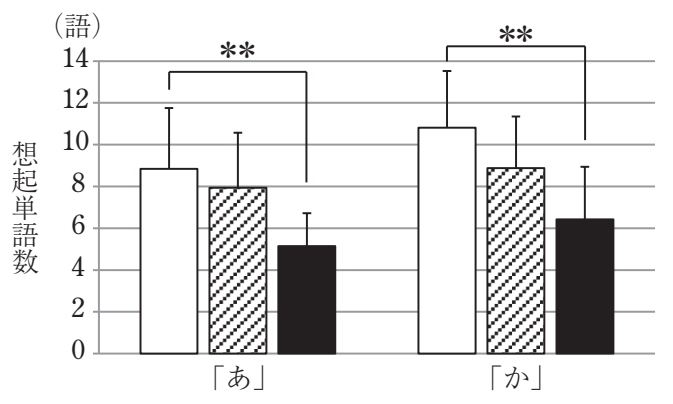

5 年生

図 1 語流暢性課題（語頭音指定）の成績

$\mathrm{RC}$ : 通常学級在籍児, $\mathrm{DD}$ : 発達性読み書き障害典型例, $\mathrm{DD}$ $+\mathrm{SLI}$ : 発達性読み書き障害/特異的言語障害併存例, ${ }^{*}: \mathrm{p}<.05$, ** : $\mathrm{p}<.01$

\section{考察}

本研究の対象となった発達性読み書き障害典型例 （DD）と発達性読み書き障害/特異的言語障害併存例 （DD+SLI）計 63 名は，全般的知能は正常域であっ たが読み書きの学習到達度が低く, 音韻能力, 視覚的 記憶および自動化能力のいずれかの障害が認められ た。一方, DD + SLI 群は, ウェクスラー式知能検査 （WISC-III，WISC-IV）の言語性 IQ（VIQ）もしくは 言語理解指数 (VCI), 全検査 IQ (FIQ もしくは FSIQ）㧍よび標準抽象語理解力検查（SCTAW）の 得点が DD 群に比して有意に低く，読み書きの学習到 達度の低さだけでなく言語発達障害の併存も認められ た。また，非語復唱課題の正答数と小学生の読み書き スクリーニング検査 $(\mathrm{STRAW})^{12)}$ における漢字単語
の音読課題において 2 群間で有意差が認められ， DD +SLI 群は DD 群よりも得点が有意に低かった，特異

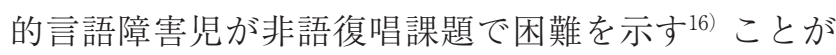
先行研究からすでに明らかにされている。ささらにUno $ら^{13)}$ は, 典型発達の小学生を対象に読み書きの学習 到達度を予測する認知機能を重回帰分析にて検討した 結果, 漢字音読力を有意に予測する変数として語彙力 が抽出されたと述べている。本研究に扔ける DD+ SLI 群の漢字音読課題と非語復唱課題の成績の低さ は, 先行研究 ${ }^{13,16)}$ の報告を反映した結果と考えられた.

本研究のテーマである語流暢性課題に関して, Snowling $ら^{2)}$ は, 語流暢性課題が音韻能力を反映し た課題であるとし， 発達性読み書き障害の検出に有用 であると述べている，本研究の対象となった発達性読 久書き障害児 63 名は，単語の逆唱課題における正答 までの所要時間の延長から音韻障害が疑われた。しか し, 通常学級在籍児 $(\mathrm{RC})$ 群と比較して, $\mathrm{DD}$ 群は 語頭音指定の語流暢性課題で得点低下を認めなかっ た. $\mathrm{RC}$ 群全例の知的機能や読み書きの学習到達度に ついて詳細な評価は行われていないため, 境界知能や 読み書きに困難を示す览童の存在を完全には否定でき ないものの, 本研究の結果は, 音声言語の発達に問題 がない発達性読み書き障害児群を対象としたBosse ら゙)と同様の結果であった。

本研究に执いて語頭音指定の語流暢性課題で得点低 下を認めたのは, DD+SLI 群であった. Snowling ら とCohen ら $ら^{5)}$ は, ともに語頭音指定の語流暢性課題 に打ける発達性読み書き障害群の成績の低さを報告し

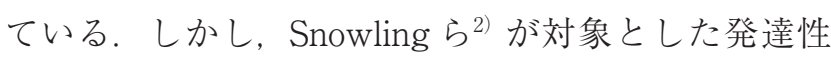
読み書き障害者群は, 統制群に比してWAIS-II (Wechsler Adult Intelligence Scale-Third Edition)「単 語」課題の評価点が有意に低かった。また, Cohen ら 5 ) が対象とした発達性読み書き障害児群は，平均 -1 標 準偏差值を基準に語流暢性課題高成績（High score） 群と低成績（Low score）群の 2 群に分類したところ, Low score 群は, High score 群と比較してWISC-II の言語性 IQ や, 理解語彙力を評価するPPVT-R (Peabody Picture Vocabulary Test, revised edition) の成績が有意に低かった，日本語話者においては，大 石ら ${ }^{6)}$ が発達性読み書き障害児 7 例のうち，5名に語 頭音指定の語流暢性課題で成績の低さを認めたと述べ ている.しかし, この 5 名は全例 WISC-R (Wechsler Intelligence Scale for Children-Revised）の言語性 IQ や埋め込み文の表出課題のような音声言語の発達を反 映する課題に扔いて, 典型発達児に比して低得点で 
あった。特異的言語障害純粋例 ${ }^{17,18)}$ や知的障害例19) のような言語発達障害を呈する対象児において語頭音 指定の語流暢性課題で低い得点を示していることから も, 語流暢性課題の成績には音声言語の発達が関与し ており, 言語発達障害の併存のない典型的な発達性読 み書き障害児は，語流暢性課題には問題を示さないと 考えられた。

一方, 本研究と先行研究との結果の相違には, 対象 の年齢が関与している可能性もある. Kinsbourne ら ${ }^{3)}$ は20 代後半の発達性読み書き障害典型群を対象に語 頭音指定の語流暢性課題を実施し, 統制群と比較して 成績の低さが認められたと報告した。また Frith ら ${ }^{4}$ は，年齢の高い発達性読み書き障害児/者の場合，た とえ検査上音声言語の発達に問題がなくても，文字を 読む経験の不足が語頭音指定の語流暢性課題の成績に 与える影響は完全には否定できないと述べている。本 研究の対象児（RC 群，DD 群および DD + SLI 群）は 小学 1,3 抢よび 5 年生であり, Snowling ら ${ }^{2)}$ Kinsbourne $ら^{3)}$ の研究と比較すると年齢が低かった。 今後は発達性読み書き障害の対象年齢を成人まで広げ て検討する必要があると考えられる。

本研究では，発達性読み書き障害児の語音想起力を 評価する課題として語頭音指定の語流暢性課題を使用 した。しかし，語流暢性課題は，符号化・貯蔵段階を 操作せずに長期記憶からの検索を要求するという課題 特徵から，語彙の記憶における検索方略の生成と使用 といった，実行機能もしくは前頭前野の機能を強く反 映した課題とも考えられており，神経心理学的検査と して脳損傷患者や認知症患者にも広く用いられてい $3^{8)}$. 本研究において, 語頭音指定の語流暢性課題で 成績の低さを認めたのは発達性読み書き障害児群のな かでも特異的言語障害併存例のみであった。しかし， 本研究の結果と実行機能との関連については明確では ない，発達期において，語流暢性課題の成績の低さに 影響を及ぼす要因が害行機能なのか語彙の豊富さなの かについては現在も論争中である ${ }^{8)}$ 。しかし，発達性 読み書き障害児や特異的言語障害児の大脳において, 機能的 MRI（Magnetic Resonance Imaging）や大脳 の構造を検討する手法であるVBM（Voxel Based Morphometry）を用いた研究において，前頭前野に 構造上の問題があるという報告はない，また，特異的 言語障害と実行機能障害との関連について言及した報 告も，筆者らが探す限り見当たらない，以上から，本 研究の結果は実行機能とは独立しており, DD + SLI 群における語頭音指定語流暢性課題の成績の低さは,
音声言語の発達を反映した結果と考えることが妥当な のではないかと思われた。

利益相反自己申告：申告すべきものなし．

\section{文献}

1) Messer D and Dockrell JE: Children's naming and wordfinding difficulties: Descriptions and explanations. J Speech Lang Hear Res, 49: 309-324, 2006.

2) Snowling M, Nation K, Moxham P, et al: Phonological processing skills of dyslexic students in higher education: A preliminary report. J Read Res, 20 (1): 31-41, 1997.

3) Kinsbourne M, Rufo DT, Gamzu E, et al: Neuropsychological deficits in adults with dyslexia. Dev Med Child Neuro, 133: 763-775, 1991

4) Frith U, Landerl $\mathrm{K}$ and Frith C: Dyslexia and verbal fluency: More evidence for a phonological deficit Dyslexia, 1: 2-11, 1995.

5) Cohen MJ, Morgan AM, Vaughn M, et al: Verbal fluency in children: Developmental issues and differential validity in distinguishing children with attention-deficit hyperactivity disorder and two subtypes of dyslexia. Arch Clin Neuropsychol, 14 (5): 433-443, 1999.

6）大石敬子, 斎藤佐和子：言語発達障害に打ける音韻の問題 一読久書き障害の場合一。音声言語医学, $40 ： 378-387$, 1999.

7) Bosse ML, Tainturier MJ and Valdois S: Developmental dyslexia: The visual attention span deficit hypothesis Cognition, 104: 198-230, 2007.

8）惠羅修吉：発達障害児を対象とした語想起課題による実行 機能の評価. 発達支援研究, $12: 19-35,2008$.

9) Crockett DJ: Component analysis of within correlations of language-skill tests in normal children. J Spec Educ, 8: 361-375, 1974.

10) DesRosiers G and Kavanagh D: Cognitive assessment in closed head injury: stability, validity and parallel forms for two neuropsychological measures of recovery. Int J Clin Neuropsychol, 9: 162-173, 1987.

11）村井敏宏, 山下 光, 小川隆夫, 他 : 小览用語想起課題作 成の試み $\mathrm{I}$ 一小学生の基準デー夕の収集一, 大阪教育大学 紀要 第IV部門，53 (1)：83-89，2004.

12）宇野 彰, 春原則子, 金子真人, 他：小学生の読及書き久 クリーニング検査一発達性読み書き障害（発達性 dyslexia）検出のために一，インテルナ出版，東京，2006.

13) Uno A, Wydell TN, Haruhara N, et al: Relationship between reading/writing skills and cognitive abilities among Japanese primary-school children: Normal readers versus poor readers (dyslexics). Read Writ, 22: 755-789, 2009.

14）春原則子, 宇野 彰, 朝日美奈子, 他：典型発達児に打け る音読の流暢性の発達と関与する認知機能についての検討 一発達性 dyslexia 評価のための基礎的研究一. 音声言語 医学, 52:263-270, 2011.

15）篠田晴男，千葉ゆき，塚田裕子，他：学齢期に㧍ける読み 
書きの基礎能力を規定する諸要因について一命名速度と音 韻認識能力を中心として一. 平成 14 年度厚生労働科学研 究報告書 (子供家庭総合研究事業) : 446-479, 2003.

16) Marshall CR: Word production errors in children with developmental language impairments. Phil Trans R Soc B, 369: 1-8, 2014.

17) Weckerly J, Wulfeck B and Reilly J: Verbal fluency deficits in children with specific language impairments: slow rapid naming or slow to name? Child Neuropsychol, 7: 142-152, 2001
18) Coelho S, Albuquerque $C P$ and Simões MR: Specific language impairment: A neuropsychological characterization. Paidéia, 23 (54): 31-41, 2013.

19) Pennington BF, Moon J, Edgin, J, et al: The neuropsychology of Down syndrome: evidence for hippocampal dysfunction. Child Dev, 74 (1): 75-93, 2003.

別刷請求先：干305-8572 茨城県つくば市天王台 1-1-1 筑波大学人間系

宇野 彰 